\title{
Oppimispäiväkirjan hyödyllisyys aikuisopiskelussa
}

\author{
Kokemuksia ideapäiväkirjan käytöstä \\ esimiesten koulutuksessa
}

Tauriainen, Pertti 1989. Oppimispäiväkirjan hyödyllisyys aikuisopiskelussa. Kokemuksia ideapäiväkirjan käytöstä esimiesten koulutuksessa. Aikuiskasvatus 9, 2, 52-57.

- Artikkelissa tarkastellaan määrämuotoisen esimieskoulutuksen ongelmia oppimaan oppimisen ja oppimisprosessin ylläpitämisen näkökulmista. Perinteisen luokkahuoneessa tapahtuvat yksilökoulutuksen käynnistämää oppimisprosessia on yritetty siirtää työpaikalla tapahtuvaksi ongelmanratkaisuprosessiksi käyttämällä apuna oppimispäiväkirjatekniikkaa. Valtionhallinnon kehittämiskeskuksessa tehtyjen kokeilujen tulosten perusteella näyttää siltä, että ideapäiväkirjatekniikka on hyödyllinen pitkäkestoisessa aikuiskoulutuksessa. Yli 2/3 kokeilussa mukana olleista koulutettavista ilmoitti hyötyneensä menetelmän käyttämisestä.

Artikkelin sisältö perustuu kirjoittajan vuosina 1987 ja 1988 toteuttamien esimiestaidon kurssien osanottajien näkemyksïn sekä koulutustilaisuuksien aikana ja nüiden jälkeen tehtyihin havaintoihin.

\section{Kokeilun lähtökohdat}

Valtionhallinnon kehittämiskeskus (VKK) järjestää vuosittain 2-3 julkisen hallinnon keskijohdolle tarkoitettua esimiestaidon kurssia. Tavoitteena on antaa osanottajille tietoja ja edellytyksiä arvioida ja kehittää omaa esimiestyöskentelyään tulosjohtamisen suuntaan. Koulutus toteutetaan 2 jaksossa. Teoriapainotteisen aloitusosuuden ( $5 \mathrm{pv}$ ) jälkeen sovelletaan saatuja oppeja käytäntöön noin kuukauden kuluttua toteutettavalla toisella jaksolla (4 pv).

Kurssin oppimiskäsitys perustuu ihmisen toimintaa ohjaavien sisäisten mallien teorian pohjalle. Vuonna 1987 lisättiin kurssin alkuun oppimaan oppimiseen johdattava jakso, jotta kurssin ensimmäisen jakson teoria-aineksen omaksumisen merkitys tulisi aikaisempaa paremmin perustelluksi.

Lisäpontta oppimistapojen kehittämiskokeiluille antoi VKK:sen koulutuksessa yleisesti vallitsevan "kansiokulttuurin" tiedostaminen. Opiskelumateriaalin valtaosan muodostavat luennoitsijoiden esittämistä piirtoheitinkalvoista otetut kopiot, jotka kurssin kuluessa kerätään kurssimappiin. Koulutuksen jälkeen mappi tavallisesti jää osanottajan hyllyyn, eikä siihen sen jälkeen juurikaan kosketa.
Kurssin toteuttajia jatkuvasti askarruttavina kysymyksinä ovat myös olleet:

- miten osanottajat saadaan itse ottamaan päävastuu oppimisesta

- miten oppimisprosessi voidaan saada jatkumaan kurssin välijaksolla

- miten koulutuksessa saadut ajatukset saadaan elämään työkäytännöissä?

\section{Oppimis-/ongelmanratkaisutavan analysointi}

Esimiestaidon kurssin kantava ajatus on, että osanottajat oppivat ratkaisemaan itse havaitsemiaan pulmallisia esimiestilanteita kurssin aikana opiskellun teoreettisen aineksen varassa. Tästä syystä kurssin alussa rinnastetaan oppiminen ja ongelmanratkaisu toisiinsa. Teoreettisen perustelun täıle iavaile on esittänyt David A. Kolb kokemuspohjaisen oppimisen mallin kehittelyn yhteydessä (Kuvio I). 


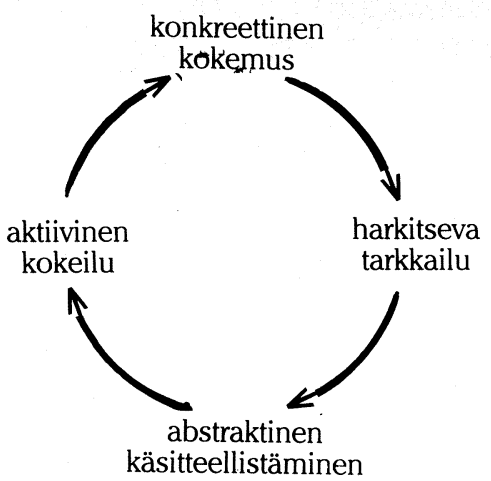

Kuvio 1. Kokemuspohjaisen oppimisen malli

Kolbin mielestä oppiminen on tärkein ihmisen muuntumisprosessi. Syklinen kokemuspohjaisen oppimisen malli voidaan nähdä heijastuksena myös monissa muissa inhimillisen muuntumisprosessin erikoismalleissa (mm. ongelmanratkaisun, päätöksenteon ja luovuuden malleissa). Yhteinen alkuidea näissä malleissa on se, että kaikki inhimillisen muuntumisen prosessit muistuttavat tieteellisen tutkimuksen prosessia (Kolb, 1984, 31-34).

Kolb on kehittänyt oppimismalliaan hahmottavan sanallisen oppimistyylitestin, jonka avulla voidaan eritellä testattavalle luonteenomaista ongelmanratkaisutapaa. Vallitsevan ongelmanratkaisutavan erittelyn tuloksena kurssilaisille kirkastuu kokemuspohjaisen oppimisen mallin syklisyyden merkitys hyvään oppimistuloksen pyrittäessä. Testi tarjoaa kullekin kurssilaiselle pohjan lähteä arvioimaan sekä tarvittaessa kehittämään omaa henkilökohtaista ongelmanratkaisutapaansa koulutustavoitteiden kannalta parhaimman oppimistavan eli täydellisen oppimisen mallin suuntaan.

\section{Opitun soveltamisen esteet}

Englantilaiset Bennett ja Richardson ovat kehitelleet Kolbin ajatuksia käytännön koulutustyössä. He korostavat, että oppiminen ja ongelmanratkaisu mielletään parhaiten yhteydessä omaan organisaatioon. Tällöin vallitsevan oppimistyylin yksilöllisyyteen vaikuttaa kurssilaisen työpaikalla vallitseva organisaatiokulttuuri. Kehittäjän kannalta näyttääkin kiinnostavaksi kysymykseksi nousevan: mikä on kurssilaisen työpaikan vallitseva oppimis-/ongelmanratkaisutapa? Bennettin ja Richardsonin ajatusten pohjalta voidaan hahmottaa yksilökoulutuksen vaikuttavuuden ongelmia seuraavan kuvion (kuvio 2) avulla (Bennett \& Richardson 1984).

Työpaikan yhteisökulttuuria eräältä osalta ilmentävä organisaation vallitseva ongelmanratkaisutapa vaikuttaa työntekijän ongelmaratkaisutapaan. Yksilökoulutuksessa työntekijä omaksuu uuden kehittyneemmän ongelmanratkaisutavan. Mikäli organisaation vallitseva ongelmanratkaisutyyli poikkeaa työntekijän omaksumasta uudesta ratkaisutyylistä, ei opittuja asioita voida soveltaa käytäntöön kovinkaan helposti. Usein käykin niin, että työntekijä varsin pian koulutuksen jälkeen lakkaa yrittämästä uuden ongelmanratkaisutavan käyttöönottamista. Chris Argyris on tutkimuksissaan kiinnittänyt huomiota ihmisen toimintaa ohjaavien todellisten mallien (käyttöteorioiden) ja ihmisen itse ilmaisemien toimintamallien (julkilausutut teoriat) välisen ristiriidan tiedostamisen tärkeyteen. Argyriksen ajatuksia vapaasti tulkiten voidaan löytää seuraava analogia:

käyttöteoria

julkilausuttu teoria vallitseva ongelmanratkaisutyyli

koulutuksessa saatu ongelmanratkaisutyyli

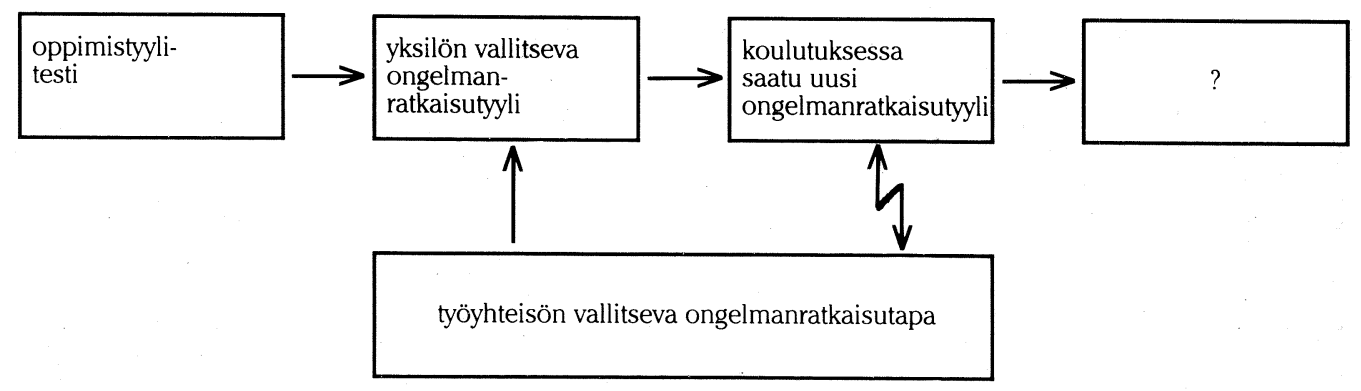

Kuvio 2. Yksilökoulutuksen vaikuttavuus 
Yksilön vallitsevan ongelmanratkaisutyylin olemassaolo voidaan selittää ja ymmärtää tavoitteellista toimintaa ohjaavan sisäisen mallin -teorian avulla. Koulutuksen alussa testatun ongelmanratkaisutyylin taustalla voitaneen olettaa olevan työyhteisön arkikäytäntöön (käyttöteoriaan) pohjautuva sisäinen malli. Koulutustilaisuudessa kurssilainen saa rakennusaineita vaihtoehtoisen sisäisen mallin kehittelyyn.

Työyhteisön vallitsevaa ongelmanratkaisutyyliä on vaikea selvittää minkään testin avulla. Hankalalta tuntuu myös työyhteisön sisäisen mallin selvittäminen, koska sellaisen mahdollinen olemassaolo kytkeytyy läheisesti organisaatiokulttuurin eräisiin piirteisiin. Hieman teoreettisesti ontuvanakin yksilön ongelmanratkaisutavan ja organisaation ongelmanratkaisutavan rinnastaminen tarjoaa opetustilanteisiin kantavan ristiriidan, jonka avulla voidaan käsitellä yksilökoulutuksen ja työpaikalla tapahtuvan kehittämistyön yhteensovittamisen kysymyksiä.

Bennett ja Richardson tuovat kirjoituksissaan esin sen, että opitun soveltamisen esteet työpaikalla voivat johtua paitsi organisaatiokulttuurista, myös organisaation rakenteellisista tekijöistä. Heidän kokemuksensa mukaan opitun soveltamisen esteiden tiedostaminen ja niiden perusteellinen käsittely koulutuksen aikana parantaa edellytyksiä käyttää kehittyneempää ongelmanratkaisutyyliä koulutuksen jälkeen.

Myös Asko Miettinen on väitöskirjassaan "Organisaatio ja koulutustulosten pysyvyys" (s. 156) tuonut esiin oppimisen siirtovaikutusta vastustavia voimia, joiden aiheuttamat ongelmat ovat samantyyppisiä kuin Bennettin ja Richardsonin havainnot työyhteisön vallitsevan ongelmanratkaisutyylin vaikutuksista.

\section{Oppimispäiväkirja oppimisprosessin osana}

Useimmat aikuisiässä pitkäkestoiseen koulutukseen tulevat henkilöt eivät perusopintojensa jälkeen ole kehittäneet opiskelutapojaan. Esimerkiksi kysyttäessä kurssilaisilta lukemiseen liittyviä asioita on toistuvasti tullut esille, että monet eivät lue ainakaan teoreettista kirjallisuutta. Vain harvat kurssilaiset ovat myöskään kunnolla perehtyneet koulutustilaisuuksien ennakkolukemistoihin.

Lukemisen ohjauksen lisäksi on VKK:ssa ollut muutakin opiskelun ja oppimaan oppimisen ohjausta jo pitkään esim. työnjohdollisessa koulutuksessa ja toimistotukinnon suorittamisen ensimmäisillä jaksoilla. Myös johdon koulutuksessa on havaittu opiskelun ohjaamisen tarvetta.

Esimiestaidon kurssilla lähdetään oppimaan oppimista tarkastelemaan seuraavan kuvion hahmottamalla tavalla (kuvio 3 ):

Kurssin alussa tuotetaan osanottajien porinryhmien avulla fläppitauluille hyvän esimiehen pätevyyskuva, eli hahmotetaan hyvän esimiehen tavoitemalli. Kurssilaisten kehittymistavoitteeksi määritellään hyvän esimiehen pätevyystavoitteiden saavuttaminen kirjallisuuteen tutustumisen, luokkahuoneoppimisen ja työssä toteutettavien kehittämiskokeilujen avulla. Keskeiseksi määrämuotoisen koulutuksen tavoitteeksi asetetaan oman ongelmanratkaisutavan (oppimistavan) tietoinen monipuolistaminen siten, että asetetut pätevyystavoitteet voidaan saavuttaa. Teoreettisen tiedon soveltamisen helpottamiseksi käytetään oppimispäiväkirjaa, johon osanottajia pyydetään kirjaamaan kehittämiskokeilujen kannalta merkittäviä oppimisideoita ("ahaa-elämyksiä").

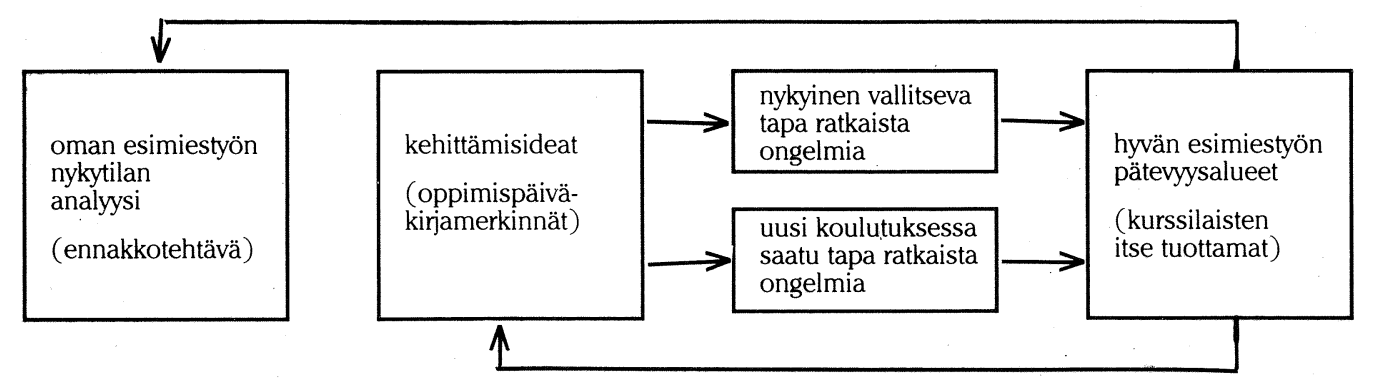

Kuvio 3. Esimiestaidon oppimisen lähtökohdat 
Oppimispäiväkirjatekniikkaa on käytetty hyväksi Ruotsissa VKK:sen pohjoismaisessa kollegaorganisaatiossa SIPU:ssa (Statens Institut för Personaladministration och utbildning). Siellä tehdyissä kokeiluissa nousi esiin hyödyllisenä menetelmänä oppimispäiväkirjojen tiivistelmissä laaditun yhteenvedon laatiminen ja kaikkien kurssilaisten oppimisoivallusten koosteen lähettäminen kurssilaisille kurssin päättymisen jälkeen.

Esimiestaidon kursseilla 1/87 ja 2/87 pyydettiin osanottajia päivittäin kirjaamaan luentokansioissa oleville irtolehdille oppimiselämyksiään ja kehittämisideoitaan. Kurssin 2. jakson lopulla tekivät osanottajat kukin A 4sivun mittaisen tiivistelmän koulutuksen aikana keskeisimmiksi kokemistaan oppimisoivalluksista. Oppimispäiväkirjojen tiivistelmät kerättiin pois osanottajilta kurssin päättyessä.

\section{Suhtautuminen oppimispäiväkirjaan}

Kolme neljännestä kurssilaisista piti kirjallisessa kurssiarviossa oppimaan oppimisen jaksoa hyödyllisenä (myönteinen, varauksellisen myönteinen suhtautuminen) esimiestaidon opiskelussa. Neljännes piti jakson merkitystä vähäisenä oman oppimisensa kannalta.

Kielteisesti oppimaan oppimisen jaksoon suhtautuneet perustelivat kantaansa $\mathrm{mm}$. seuraavasti:

- en tiedä opinko oppimaan — ehkä tiedostamaan oppimistarpeita

- varmaan tärkeää kouluttajille, en itse kokenut tärkeänä

— kysymyksessä on niin vaikea sasia, että sitä täytyy sulatella pidemmän ajan kanssa

- vanhaa rutiinia, silti yleensä tärkeää

- tuntui pakonomaiselta, pidin enemmän oheiskirjoittelustani

— enpähän pitänyt oppimispäiväkirjaa.

Yleisin syy jakson kielteisiin arviointeihin näyttää olevan oppimispäiväkirjan pitämisen hyödyllisyyden aliarvinoinnissa. Oman oppimistavan hahmottamiseen ja sen kehittämiseen olisi ilmeisesti pitänyt kiinnittää suurempaa huomiota paitsi kurssin alussa ja lopussa, myöskin sopivissa yhteyksissä kurssijaksojen aikana.

Kurssilla käynnistyneen oppimisprosessin jatkumista pyrittiin kartoittamaan ja ylläpitämään lähettämällä 2 kuukautta kurssin jälkeen osanottajille yhteenveto kaikkien kurssilaisten oppimispäiväkirjojen tiivistelmistä. Samassa yhteydessä pyydettiin koulutukseen osallistuneita arvioimaan oppimispäiväkirjojen ja niiden yhdistelmän merkitystä esimiestaitojensa kehittämisessä. Lisäksi vastaajat saivat tuoda esiin kurssilla saamiensa ideoiden soveltamisen esteitä työpaikoillaan.
Vain hieman yli kolmannes kurssilla olleista vastasi kyselyyn. Valtaosa vastanneista (15) koko oppimispäiväkirjatyöskentelyn joko tärkeäksi tai hyödylliseksi omien esimiestaitojensa kehittämistä edistävän oppimisprosessin kannalta. Kaksi vastaajaa ei kokenut työskentelytavalla olleen merkitystä omalle oppimiselleen.

Verrattaessa vastaajien suhtautumista oppimaan oppimiseen ja oppimispäiväkirjatekniikkaan kurssin loppuarvioinnin yhteydessä, jolloin neljännes osanottajista suhtautui varauksellisesti, näyttää ilmeiseltä, että oppimispäiväkirjatekniikkaan varauksellisesti suhtautuneet ovat muita useammin jättäneet vastaamatta jälkitiedusteluun. Varauksellisia kannanottoja perusteltiin mm. seuraavasti:

- en oikein hyvin löytänyt oppimispäiväkirjaa kurssilla, joten siitä ei paljonkaan ollut hyötyä

- merkitys ei kovin suuri, koska asiat avautuvat vähä vähältä - eivät oppimistilanteessa niinkään kuin juuri työpaikalla jälkikäteen.

Kurssien jälkitiedustelussa kysyttiin myös kurssin aikana syntyneiden kehittämisideoiden soveltamisen esteitä. Vaikka vastausprosentti jäikin alhaiseksi, on mielenkiintoista tarkastella saatuja vastauksia. Kurssilaisten kokemat opitun soveltamisen esteet voidaan ryhmitellä seuraavasti:

— ei esteitä työpaikalla

- oma saamattomuus

- liikaa omia rutiinitehtäviä

- organisaation rakenne ja toiminnan ohjaus

- virastokulttuuri

- muut päälliköt eivät ole saaneet samaa koulutusta

- hankalat ihmiset ja ihmissuhteet

— ei nimettyä soveltamisen estettä 5

2 vastausta

2 "

$2 \quad "$

"

. "

Pyrittäessä tulkitsemaan soveltamisestettä nimeämättömien vastauksia näyttää ilmeiseltä, että eräs este on oman kehittämishalun vähäisyys. Tulkintaa voi perustella vastaajien kehittämisoivalluksia tarkastelemalla. Ne olivat suurelta osalta sellaisia, jotka on mahdollista toteuttaa esimiehen omassa yksikössä. Suurimmaksi soveltamisen esteeksi näyttääkin perimmältään nousevan kurssilaisen oman kehittämishalun vähäisyys. Seuraavaksi yleisimmät esteet liittyvät organisaation rakenteeseen, työnjakoon ja toiminnan ohjaukseen. 


\section{kehittämismuistikirjaksi}

Vuonna 1987 toteutettujen esimiestaidon oppimiskokeilujen tuloksena kävi ilmi, että luokkahuoneopetuksessa voidaan antaa kurssilaisille lähinnä ajattelu- ja analyysimalleja sekä synnyttää toiminnan kehittämisoivalluksia. Kehittämisideoiden kokeilu ja todellinen muutostyö tapahtuu vasta määrämuotoisen koulutuksen ulkopuolella.

Oppimispäiväkirjojen hyödyllisyyttä koskevien selvitysten eräs viesti näyttää olevan se, että kurssikansioissa oleva oppimispäiväkirjan lehti saatetaan mieltää kouluttajien kurssiaikaiseksi apuvälineeksi eikä kurssilaisten omaksi kehittämisen työvälineeksi.

Vuonna 1988 toteutettuja esimiestaidon kursseja varten kehitettiin oppimispäiväkirjan irtolehdistä pienen A 5-kokoisen vihkon muotoon monistettu kehittämismuistikirja. Lyhyen käyttäjäohjeen lisäksi muistikirjä sisältää viitekehykset seuraavista asioista:

- oppimistyylitestiin pohjautuvan ongelmanratkaisun vaiheet

- kehittämiestyön yleinen toimintamalli

- muutoksen toteuttamisen esteet ja muutosprosessin vaiheet.

Suurin osa muistikirjasta on varattu kurssilaisten omien oppimisoivallusten ja kehittämisideoiden muistiin merkitsemistä varten. Muistikirjan aukeaman oikealle sivulle pyydettiin merkitsemään konkreettisia kehittämisideoita ja oppimisoivalluksia. Vasemmalle sivulle pyydettiin merkitsemään opitun soveltamisen esteitä omalla työpaikalla, omia henkilökohlaisia tuntemuksia, mieltä askarruttamaan jääneitä kysymyksiä jne.

Esimiestaidon kurssien 1/88 ja 2/88 alussa teetettiin kurssilaisilla oppimistyylitesti ja asetettiin hyvän esimiehen kehittymistavoitteet samoin kuin vuonna 1987 toteuteuilla esimiestaidon kursseilla. Sen jälkeen käytiin perusteellisesti läpi kehittämismuistikirjan viitekehykset ja muistikirjan käytön idea. Erityisesti korostettiin omien henkilökohtaisten tuntemusten kirjaamisen tärkeyttä, koska esimiestaitojen oppiminen edellyttää omien asenteiden ja suhtautumistapojen muuttamista. Tällöin ei tulla toimeen pelkästään viileän kognitiivisella aineksella, vaan tunteet ja tahto (myös arkielämässä tiedostamattomat asiat) voivat olla ratkaisevia tekijöitä todelliseen muutokseen pyrittäessä.
Suhtautuminen kehittämismuistikirjaan vaihteli suuresti kursseilla 1/88 ja 2/88. Esimiestaidon kurssilla $1 / 88$ olleista 24 :stä osanottajasta 22 piti kurssiarviossa oppimaan oppimisen jaksoa ja kehittämismuistikirjatekniikkaa hyödyllisenä esimiestaitojensa oppimisen kannalta. Sen sijaan jälkimmäisellä kurssilla lähes kolmannes osanottajista piti kehittämismuistikirjan merkitystä pienenä omien esimiestaitojensa oppimisen kannalta. Viimeksi mainuttu kurssi 2/88 suhtautui kokeilussa mukana olleista kursseista oppimispäiväkirjaan kaikkein negatiivisimmin. Eräs selitys saattaa olla se, että kurssilla oli joitakin sille "väkisin määrättyjä" osanottajia. Muutaman avoimesti kielteisen opiskelustrategian valinneen kurssilaisen vaikutus heijastui myös muiden kurssilaisten käyttäytymisessä osanottajien omaan aktiivisuuteen perustuvissa työskentelyvaiheissa.

Esimiestaidon kurssien 1/88 lopussa osanottajat laativat yhden A 4 -sivun mittaisen tiivistelmän kehittämismuistikirjaaan kokoamistaan keskeisistä oppimisoivalluksista. Nimettömät tiivistelmät kerättiin pois kurssin päättyessä. Kurssilaisille lähetettiin samoin kuin edellisenä vuotena 2 kuukautta kurssin jälkeen yhteenveto kaikkien osanottajien kehittämismuistikirjojen tiivistelmistä. Osanottajilta kysyttiin perusteltua mielipidettä kehittämismuistikirjojen ja niiden tiivistelmän merkityksestä esimiestaitojen kehittämisessä. Kyselyn vastausprosenttia yritettiin nostaa yhden "karhukirjeen" avulla.

Oppimisprosessin jatkumista ja kehittämismuistikirjojen hyödyllisyyttä koskevaan kyselyyn vastasi yhteensä 15 kurssilaista. Vastausprosentti oli siten yli 60 . Vastaajista 12 piti kehittämismuistikirjatekniikkaa sekä tiivistelmien ja yhteenvetojen laatimista hyödyllisenä omien esimiestaitojensa kehittämisessä. Myös varauksellisesti esitettyyn kysymykseen vastanneet 3 kurssilaista näkivät tarpeelliseksi jonkinlaisen kehittämisideoiden kirjaamistavan.

Esimiestaidon kurssin 2/88 ensimmäisen jakson aikana käsitellyt asiat kerrattiin toisen jakson alussa kehittämismuistikirjamerkintöjen pohjalta ryhmätyänä. Ryhmiä pyydettiin tuottamaan piirtoheitinkalvoille sekä ensimmäisen jakosn keskeisiä oppimisoivalluksia että epäselviksi jääneitä asioita. Toisen jakson luennoitsijat ja harjoitusten vetäjät käyttivät saamaansa palautetietoa oman opetuksensa suuntaamisessa. 


\section{Johtopäätöksiä}

Oppimaan oppimiseen johdattava jakso ja ideapäiväkirjatekniikka ovat osoittautuneet tarpeellisiksi 2-jaksoisen esimiestaidon kurssin osana. Vähintään $2 / 3$ kurssilaisista näyttää hyötyvän ideapäiväkirjatekniikan käyttàmisestä. Ideapäiväkirjaa voidaan käyttää kurssin 1. jakson kertauksessa sekä osanottajien että kouluttajien apuvälineenä. Ideapäiväkirjojen tiivistelmien ja niiden yhteenvedon avulla saadaan oppimisprosessia ylläpidettyä kurssin päättymisen jälkeen. Selvitysaineiston perusteella näyttää siltä, että arviolta puolet esimiestaidon kurssilaisista hyötyy ideapäiväkirjojen tiivistelmien yhteenvedosta.

Ideapäiväkirjan ilmiasulla näyttää olevan merkitystä. Pienen kehittämismuistikirjan muotoon tehty versio tuottaa paremman tuloksen kuin kurssikansioon monistetut irtolehdet.

Erittäin tärkeää näyttää olevan se, että kehittämismuistikirjan käyttöön ottaminen perustellaan oppimaan oppimisen ja kurssilaisten oman ongelmanratkaisuvaatimuksen avulla.
Ideoiden muistiin merkitsemistä kannattaa aluksi yhdessä harjoitella esim. varaamalla 1015 minuuttia päivän alussa edellisen päivän oppimisoivallusten muistiin merkitsemiseen.

\section{Lähteet}

Bennett, Ben \& Richardson, Jim 1984. Applying Learning Techniques to On-the-job Development. Journal of European Industrial Training 1984: 1, 3,4 .

Kolb, David A. 1984. Experiental Learning. Experience as the Source of Learning and Development. London: Prentice Hall.

Miettinen, Asko 1978. Organisaatio ja koulutustulosten pysyvyys. Helsingin Yliopiston väitöskirja. 


\section{AIKUISKASVATUS}

\section{The Finnish Journal of Adult Education}

Vol. 9,2/89

ISSN 0358-6197

Summary

Perti Tauriainen 1989. The usefulness of a learning diary for adult studies. Experiences on using an idea diary in managerial training. Aikuiskasvatus 9, 2.

The article examines the problems in a set form of managerial training from the points of view of learning to learn and maintaining the learning process. An attempt has been made to transfer the learning process initiated by traditional individual education in the classroom to a problem solving process taking place at the work place by employing the old learning diary technique. Trials carried out at the Government Development Centre indicate that this technique is useful during lengthy adult education courses. More than $2 / 3$ of those involved in the trial reported having benefited from the technique.

The contents of the article are based on the opinions of participants on managerial courses arranged by the author in 1987 and 1988 and on observations made during and after the courses. 